\title{
Fish disease study of Asian seabass (Lates calcarifer) in a floating marine cage: Endoparasite and blood profile
}

\author{
DEWI HIDAYATI ${ }^{1, \vartheta}$, ANNISAA RIZQI NURINDRA ${ }^{1}$, NURLITA ABDULGANI ${ }^{1}$, EDWIN SETIAWAN $^{1}$, \\ NOVA MAULIDINA ${ }^{1}$, NUR SYAHRONI ${ }^{2}$, YEYES MULYADI ${ }^{2}$ \\ ${ }^{1}$ Department of Biology, Faculty of Science and Data Analytics, Institut Teknologi Sepuluh Nopember. Jl. Teknik Mesin No. 173, Keputih, Sukolilo, \\ Surabaya 60115, East Java, Indonesia. Tel./fax.: +62-31-5963857, `email: dewi_hidayati@ymail.com \\ ${ }^{2}$ Department of Ocean Engineering, Faculty of Marine Technology, Institut Teknologi Sepuluh Nopember. Jl. Teknik Mesin No.173, Keputih, Sukolilo, \\ Surabaya 60115, East Java, Indonesia
}

Manuscript received: 24 May 2021. Revision accepted: 27 September 2021.

\begin{abstract}
Hidayati D, Nurindra AR, Abdulgani N, Setiawan E, Maulidina N, Syahroni N, Mulyadi Y. 2021. Fish disease study of Asian seabass (Lates calcarifer) in a floating marine cage: Endoparasite and blood profile. Biodiversitas 22: 4505-4511. The Indonesian government has multiple targets and priority programs to increase aquaculture productivity in 2021. Hence, the development of mariculture commodities such as Asian seabass (Lates calcarifer) in one of the potential coastal areas, Sendang Biru, is strategic. However, sustainable productivity needs good management, including the health monitoring of fish. This study aimed to determine the condition of seabass under mariculture in a floating cage in Sendang Biru, Malang, Indonesia. Thirty seabass (Lates calcarifer) from 0 to 60 days after stocking age (ASE) were taken from a Sendang Biru floating cage. Blood and intestine samples were taken five times from day 0 to day 60 ASE. Blood samples were carried out through the caudal vein and observed using a hemocytometer. Endoparasite analysis was performed by fish intestine examination from the anterior intestine to the posterior rectum. Pseudoterranova and Diphyllobothrium were found with $10 \%$ and $3.33 \%$ prevalence, respectively. The intensity of Pseudoterranova was one individual/fish, and that of Diphyllobothrium was 2.33 individuals/fish. The highest mean of total erythrocyte count (TEC) found in 0 day ASE was at the level of $0.82 \pm 0.55 \times 106$ cells $/ \mathrm{mm}^{3}$, and the lowest was found in 60 days ASE $\left(0.51 \pm 0.24 \times 106 \mathrm{cells} / \mathrm{mm}^{3}\right)$. The highest mean of total leucocyte count (TLC) was $9.20 \pm 3.69 \times 104$ cells $/ \mathrm{mm}^{3}$, at day 0 , and leukocyte levels tended to decrease until day 60 ASE $\left(7.74 \pm 3.43 \times 104\right.$ cells $\left./ \mathrm{mm}^{3}\right)$. Overall, despite the TEC and TLC tending to decrease from 0 to 60 days ASE, in statistically indicated no significant differences in TLC at different ASEs ( $p>0.05$ ). The hematological profile indicated the health statuses of the cultured Asian seabass in the current study were in a condition of anemic and infected.
\end{abstract}

Keywords: Asian seabass, blood profile, endoparasite, fish disease, intensity, Lates calcarifer, prevalence

\section{INTRODUCTION}

Indonesia is an archipelago with more than 17,500 islands, and its coastline measures more than $81,000 \mathrm{~km}$. It has a warm tropical climate throughout the year and thus has great potential for the development of mariculture. In 2019, the potential area for mariculture reached 12.1 million hectares, with the utilization of $2.36 \%$, while the potential areas for brackish and aquaculture were 2.88 million hectares with $2.88 \%$ utilization and 2.83 million hectares with $11.32 \%$ utilization, respectively (Asdary et al. 2019). Based on these data, mariculture has the highest potential, but its utilization is still relatively low. The Directorate General of Fisheries increased the target fishery production by $16.07 \%$ per year, from 19.5 million tons in 2015 to 31.3 million tons in 2019 (DPJB 2017). Accordingly, the development of prospective areas of mariculture in Indonesia is essential. Besides natural resources, successful mariculture production also requires health management and regular monitoring. Asian seabass (Lates calcarifer) is a mariculture commodity with a high level of tolerance to salinity and is adaptable to mariculture systems (Siddik et al. 2019; Hastuti et al. 2020).
In general, like other animals, cultured fish are susceptible to parasitic, bacterial, and viral infections (NOAA 2019). The risk of disease transmission is the crucial element that must be controlled since the water moves freely toward the floating cage and could contain infectious parasites and pollutants (Alagić 2009). Parasites in fish can interfere with the development of aquaculture (Ruckert et al. 2008). Parasites are organisms whose life depends on the host by adapting to the host. Endoparasites are considered more risk than ectoparasites since their damage to the host's organs is more extensive (Ashraf and Zafar 2013). Some endoparasites are zoonotic, such as cestodes, trematodes, nematodes, and Acanthocephala, and can infect humans by consuming raw or undercooked fish (Eiras et al. 2016; Shamsi 2019). Pseudoterranova and Diphyllobothrium are examples of important zoonotic fishborne nematode and cestode parasites, respectively. The free-swimming larvae of Pseudoterranova would be eaten by fish, and if consumed by humans, the larvae would successfully remain and burrow into the gastrointestinal tract (Bennett et al. 2015). Fish may be infected by Diphyllobothrium after eating infected copepods. It would then be accidentally ingested by humans and lead to the disease of Diphyllobothriasis (Scholz et al. 2009). Up to 20 
million humans are estimated to be infected worldwide (REF?). Based on previous studies, endoparasites have been found in both captured and cultivated seabass in where? (Hutson 2014). However, fewer endoparasites have been found in cultivated seabass because of mariculture's more controlled conditions (Ruckert et al. 2008).

Blood profile, or hematology, is a parameter commonly used to determine the condition of fish because it is sensitive to environmental changes like water quality, oxygen, temperature, and salinity (Parrino 2018). According to Panjvini et al. (2016), who studied Cyprinus carpio, parasitic infections cause hematological changes, including increased leukocytes, associated with defense mechanisms and immunological response to infection. The hematological study provides relevant information regarding cultivated fish's physiological capacity and evaluates their immunological state (Corrêa et al. 2015).

In this study, endoparasite and blood profile analyses were carried out to determine the prevalence and intensity of endoparasites and hematological levels in Asian seabass cultured in a marine floating cage. The location of the Sendang Biru waters in the Malang District of Indonesia (Figure 1) was selected due to its fishery potential (Hidayati et al. 2019). This investigation provides valuable data about the healthy management of cultured fishes, which is advantageous to mariculturists and natural resource managers (NOAA 2019).

\section{MATERIALS AND METHODS}

\section{Study area}

Seabass samples were taken from floating cages located in the coastal waters of Sendang Biru, Malang District, East Java, Indonesia (Figure 1), at $8^{\circ} 26^{\prime} 14.90^{\prime \prime} \mathrm{N}$; $112^{\circ} 40^{\prime} 47.80^{\prime \prime} \mathrm{E}$.

\section{Procedures}

\section{Sampling procedure}

One hundred individuals of three-month-old Asian seabass juveniles, with body lengths of $10.7 \pm 0.4 \mathrm{~cm}$ and weights of $17.8 \pm 0.5$ gram, were cultured in a floating cage measuring $4 \mathrm{~m} \times 4 \mathrm{~m} \times 4 \mathrm{~m}$. According to Aldon (1997), the stocking density of two-to-three-month-old Asian seabass is $10-20 \mathrm{fish} / \mathrm{m}^{2}$. Thus, the density of cultivated fishes in the current study was low, i.e., 6-7 fish $/ \mathrm{m}^{2}$. The floating cage was made from high-density polyethylene with double nets having $1 \mathrm{~cm}$ and $2 \mathrm{~cm}$ diameters. The cultivated fish were fed pellets and fish trash two times a day, in the morning and evening, with a feed weight of $10 \%$ of the total weight of the fish. The mean fish's survival rate (SR) at 60 days after stocking age (ASE) was $80 \%$. The SR value indicated that the cultivated fish successfully acclimated to the floating cage. A total of 30 fish samples among the surviving fish during the 60 days of cultivation were collected for both blood and endoparasite analysis. Sampling was divided into five sampling times $(0$, $14,30,45$, and 60 days ASE), and each sampling time consisted of six fish samples. The selected fifteen-day interval in the current study was adopted from Korytár et al. (2019), investigating the relationship between erythrocyte and parasite invasion in fish.

The fish were collected from the floating cage using a sampling net modified with a long holder stick prior to preparing blood and endoparasites samples. The blood sampling method followed the ethical considerations for field research on fish suggested by Bennett et al. (2016). Blood samples were taken from the caudal fins of anesthetized fish using sharp needles to minimize pain. The blood samples were taken using a $1 \mathrm{ml}$ syringe containing $0.1 \mathrm{ml}$ of $10 \%$ anticoagulant potassium salt of ethylene diamine tetra-acetic acid (EDTA) solution. Then, they were stored in microtubes and preserved in a cool box containing dry ice. After blood sampling, the fish were euthanized prior to the endoparasite sampling process. The fish were dissected by making an incision in the ventral part of the fish. The digestive tract was removed and placed in a sample container that had been previously filled with $5 \%$ formalin as a buffer. Collected samples were then immediately transported to the laboratory and refrigerated for further analysis.

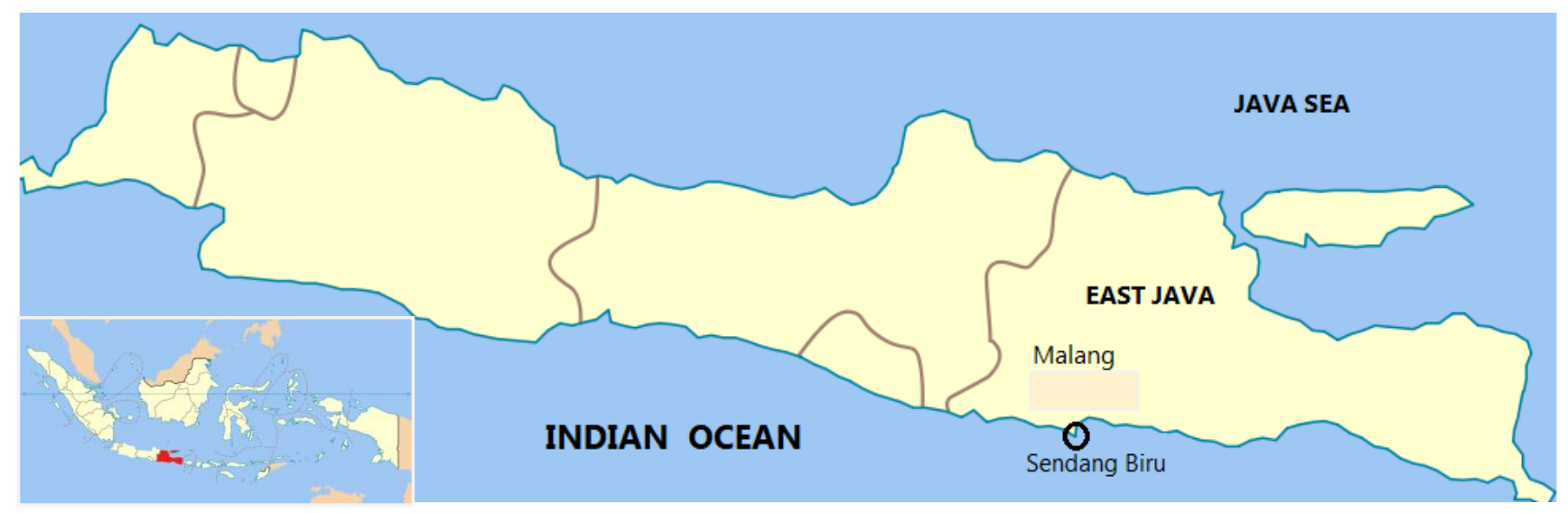

Figure 1. Location of floating cages in the inshore waters of Sendang Biru (black circle), Malang District, East Java, Indonesia 
Water quality measurement

Water quality parameters, i.e., salinity (\%), $\mathrm{pH}$, dissolved oxygen $(\mathrm{mg} / \mathrm{L})$, and temperature $\left({ }^{\circ} \mathrm{C}\right)$, were measured on-site using a refractometer (Atago), a portable pH meter (Hanna HI 98107), and a portable water quality analyzer (NPT-DO601) for dissolved oxygen and temperature measurement, respectively. Triplicate water quality measurements were carried out inside the floating cage and in the surrounding water with temporal replication in the first and second months of the cultivation period.

\section{Endoparasite analysis}

The luminal sections of the preserved digestive tracts from the anterior intestine to the posterior rectum were opened using dissecting scissors. The fish intestine examination The lumen contents were scraped and placed into a petri dish. A suspension was created by adding several drops of $5 \%$ formalin that had previously been used to preserve the digestive tract. The suspension sample was transferred onto glass microscope slides with cavities and observed under a compound microscope connected to a photomicroscope at 40x, 100x, and 400x magnifications. If the endoparasites were too large, such as adult-stage nematodes, they were observed using a stereomicroscope. This observation procedure was repeated until each suspension of lumen contents was used up. The endoparasites found were documented prior to identification.

\section{Calculation of endoparasite prevalence and intensity}

The method for calculating endoparasite prevalence and intensity was adopted from Ruckert et al. (2008). Prevalence $(\mathrm{P})$ is the number of fish samples infected by one or more parasite species divided by the number of examined fish samples and expressed as a percentage.

\section{Prevalence $=\frac{\text { The number of infected fish }}{\text { The number of examined fish }} \times 100 \%$}

Intensity (I) is the number of individuals of a particular parasite species in the infected hosts and is expressed in numerical form.

Intensity $=\frac{\text { Total number of individuals particular parasite }}{\text { The number of infected fish }}$

\section{Hematological analysis}

Following Schaperclaus et al. (1991) and Kumar et al. (2015), the hematological parameters used in this study were the numbers of erythrocytes (RBC) and leukocytes (WBC). The blood samples were prepared using a Thoma pipette to make a suspension of the blood and diluting fluid (Hayem's solution and Turk solution for RBC and WBC, respectively), with a dilution factor of 1:200. The suspensions in the Thoma pipettes were shaken for 3-5 minutes prior to being transferred into the counting chamber of an Improved Neubauer hemocytometer. Under a microscope at $400 x$, red blood cells were counted in the five squares of the central square in the hemocytometer, and the numbers of erythrocytes and leukocytes were calculated using the following formulas:

\section{Total erythrocyte count: $\mathrm{TEC} / \mathrm{mm}^{3}=\mathrm{N} * 10,000$}

Where TEC is the total erythrocyte count; $\mathrm{N}$ is the total erythrocytes counted in the five squares in the center of the hemocytometer; and 10000 is the factor obtained after considering the initial dilution factor.

\section{Total leucocyte count: $\mathrm{TLC} / \mathrm{mm}^{3}=\mathrm{N} * 500$}

Where TLC is the total leucocyte count; $\mathrm{N}$ is the total leucocytes counted in the four large squares in the corner of the hemocytometer; and 500 is the factor obtained after considering the initial dilution factor.

\section{Data analysis}

Data were semi-quantitatively analyzed to determine the fish's health status. The TEC and TLC results were compared with normal TEC and TLC levels (Anderson et al. 1996; Izwar et al. 2020). The prevalence and intensity values of endoparasites were used to analyze the health status, as suggested by Williams and Bunkley-Williams (1996).

\section{RESULTS AND DISCUSSION}

\section{Water quality in the floating cage area}

Water quality measurements in the floating cage, including temperature, salinity, $\mathrm{pH}$, and $\mathrm{DO}$, were in the range suitable for the survival of biota, according to the Indonesian Minister of Environment Decree (Table 1).

Several previous studies have reported the optimal water quality values for the growth of Asian seabass: temperature of 22-35oC (Thépot and Jerry 2015); DO of 48; pH of 7.5-8.5; and salinity of 10-30 ppt (Jamerlan and Coloso 2010; Madrones-Ladja and Catacutan 2012). Based on these previous studies, salinity in the floating cage (34.8-36.2 ppt) and surrounding water (34.0-36.0 ppt) was relatively higher than the permissible value for Asian seabass growth. The survival of Asian seabass in floating cages might be related to their tolerance for high salinity levels of up to 50 ppt (Schipp et al. 2007).

\section{Composition, prevalence, and intensity of endoparasites}

We identified two kinds of endoparasites in the digestive tracts of the fish samples, including one genus from Cestoda (Diphyllobothrium at the egg stage; Figure 2.A) and one genus from Nematoda (Pseudoterranova at the larvae stage; Figure 2.B). The Pseudoterranova larvae found in this study had a reddish body with an elongated body length of $7.418 \mathrm{~mm}$, which indicated that they were in the L3 stage. Al Quraishy et al. (2019) explain that the body length of Pseudoterranova larvae ranges from 6.8 to $8.6 \mathrm{~mm}$, and body width, $0.16-0.21 \mathrm{~mm}$. Ruckert et al. (2008) report that each individual of Asian seabass cultured in Hurun Bay, Lampung, Indonesia, was infected with at least two parasite species. Most of the endoparasitic helminths, including digenean, cestode, and nematode, occurred with a prevalence below $26 \%$. 
Table 2 shows that the Diphyllobothrium had a prevalence value of $10 \%$ and an intensity of 2.33 individuals/fish. Pseudoterranova was found with a prevalence value of $3.33 \%$ and an intensity of one individual/fish. Ruckert et al. (2008) state that endoparasites with a prevalence below $26 \%$ are categorized as low prevalence. The controlled conditions in floating net cages, such as feeding, may lower the risk of the transmission of endoparasites from natural foods. In addition, endoparasites are heteroxenous, meaning that their life cycle requires more than one host or requires intermediate hosts. The low prevalence of endoparasites in floating net cages is due to the adaptability of parasites in the host body, the ability of the host to survive against parasites, and the quality of the aquatic environment (Agustina et al. 2018). This low prevalence is possibly caused by the monoculture system of the floating cages, which potentially lowers the risk of transmission via other cultured animals such as mollusks, shrimp, and other crustaceans, which can be intermediate hosts because of the feeding habits of cultured Asian seabass (Pozio 2015). The values of parasite intensity were in the range of 1-5, and hence, the level of endoparasite infection in Asian seabass cultured in our Sendang Biru floating cage was categorized as light (Table 2).

Table 1. Water quality in the floating cage area

\begin{tabular}{|c|c|c|c|c|c|c|c|c|c|}
\hline \multirow{3}{*}{ Parameter } & \multicolumn{4}{|c|}{ Floating cage } & \multicolumn{4}{|c|}{ Surrounding water } & \multirow{3}{*}{$\begin{array}{l}\text { Water quality } \\
\text { standard* }\end{array}$} \\
\hline & \multicolumn{2}{|r|}{ Month 1} & \multicolumn{2}{|c|}{ Month 2} & \multicolumn{2}{|r|}{ Month 1 } & \multicolumn{2}{|c|}{ Month 2} & \\
\hline & $\mathbf{n}$ & range & $\mathrm{n}$ & range & $\mathbf{n}$ & range & n & range & \\
\hline Temperature $\left({ }^{\circ} \mathrm{C}\right)$ & 6 & $22.0-22.0$ & 6 & $21.3-22.1$ & 6 & $21.8-22.4$ & 6 & $22.0-22.6$ & Natural $^{\mathrm{a}}$ \\
\hline Salinity (ppt) & 6 & $34.8-36.2$ & 6 & $35.0-35.0$ & 6 & $34.0-36.0$ & 6 & $34.0-34.0$ & Natural $^{b}$ \\
\hline $\mathrm{pH}$ & 6 & $7.3-7.3$ & 6 & $7.4-7.4$ & 6 & $7.4-7.6$ & 6 & $7.5-7.5$ & $7-8.5$ \\
\hline DO & 6 & $7.3-7.5$ & 6 & $7.3-7.9$ & 6 & $7.6-8.0$ & 6 & $7.5-7.7$ & $>5$ \\
\hline
\end{tabular}

*Anonymous (2004): Quality standard refers to the Indonesian Minister of Environment Decree No. 51/ Year 2004; ${ }^{\text {a }}$ It is permissible to change not more than $2^{\circ} \mathrm{C}$ from natural temperature; ${ }^{b}$ It is acceptable to change not more than $5 \%$ from the seasonal mean salinity.

Table 2. Prevalence (P) and intensity (I) of endoparasites in cultured Asian seabass in Sendang Biru floating cage

\begin{tabular}{lccccccc}
\hline $\begin{array}{c}\text { Endoparasite } \\
\text { (Genus) }\end{array}$ & $\begin{array}{c}\text { No. of } \\
\text { fish samples }\end{array}$ & $\begin{array}{c}\text { No. of } \\
\text { infected fish }\end{array}$ & $\begin{array}{c}\text { No. of } \\
\text { endoparasites }\end{array}$ & P (\%) & I & \multicolumn{2}{c}{$\begin{array}{c}\text { Criteria of parasite infection Williams } \\
\text { and Bunkley-Williams (1996) }\end{array}$} \\
\hline $\begin{array}{l}\text { Pseudoterranova } \\
\text { Diphyllobothrium }\end{array}$ & 30 & 1 & 1 & 3.33 & 1 & Occasionally & Light \\
\hline
\end{tabular}
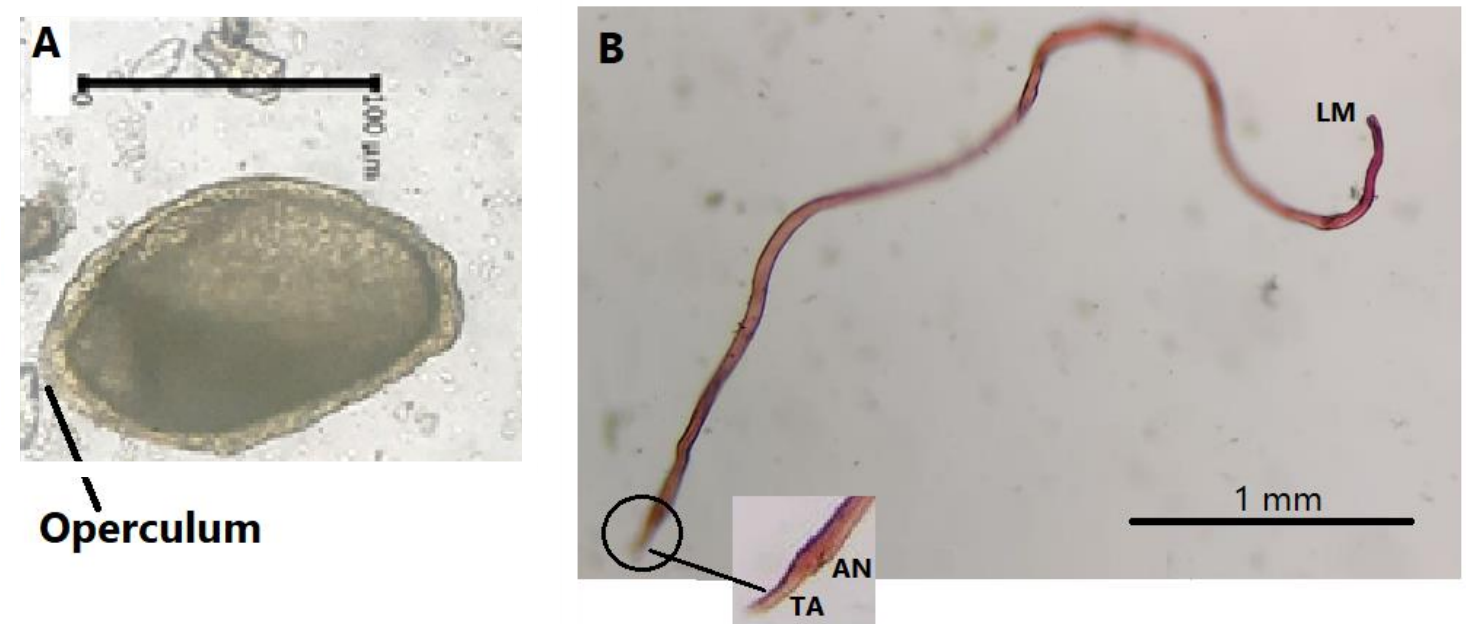

Figure 2. A. Diphyllobothrium egg. B. Pseudoterranova larvae (L3) showed a reddish, elongated body with the lateral mouth (LM) in the anterior part and a transverse annulation cuticle (TA) and anus (AN) at the posterior part 
Diphyllobothrium requires several hosts in its life cycle. Immature eggs are released via feces into free water. Adult eggs will hatch and develop into coracidia, namely, oncospheres with cilia then the coracidia are eaten by planktonic copepods (Lopez et al. 2020). The coracidia develop into first-stage larvae called procercoids, which may be eaten by planktonic copepods that act as the first intermediate host. Then, the copepods are fed by the second intermediate host, such as small fish, so that the larvae develop into second-stage larvae or metacestodes, called plerocercoids. When larger fish prey on the second intermediate host, the plerocercoids can migrate toward muscle or meat. The larvae develop into adult worms in definitive hosts, such as marine mammals and humans. Adult worms will attach to the intestinal wall using bothria on the scolex (Kuchta et al. 2013; Lopez et al. 2020). Since the Asian seabass juvenile is an omnivore and opportunist predator, the Pseudoterranova larvae might enter their bodies through predation. The small fishes or crustaceans that can act as intermediate hosts for parasitic worms are the main diet of juvenile Asian seabass (Agustina et al. 2018).

Accordingly, we assumed that Diphyllobothrium and Pseudoterranova in Asian seabass intestines might be transmitted from larvae in the body of ingested natural food such as planktonic crustaceans. Diphyllobothrium lives in the intestinal tract of fish and usually, in a certain amount, does not cause serious disease. Severe infection is characterized by a swollen stomach in the fish (Jithendran and Kannappan 2010). In the current research, we did not find any pathological symptoms in the observed fish. This condition was in line with Williams and BunkleyWilliams's criteria (1996), which stipulate that fishes with parasite intensity values of 1-5 indicated light infection. However, the L3 stage of Pseudoterranova can be dangerous since they are zoonotic and possibly enter the human body through infected fish (Pozio 2015). Therefore, proper handling and cooking of these fish are recommended.

\section{Hematological profiles}

The mean of TEC in Asian seabass cultured in our Sendang Biru floating cage from $0 ; 14 ; 30 ; 45$, and 60 days ASE were in the level of $0.82 \pm 0.55 \times 106 ; 0.62 \pm 0.23 \times 106$; $0.69 \pm 0.29 \times 106 ; \quad 0.70 \pm 0.30 \times 106$ and $0.51 \pm 0.24 \times 106$ cells $/ \mathrm{mm}^{3}$ respectively (Figure 3 ). The one-way analysis of variance (ANOVA) revealed no significant differences of TEC at different ASEs $(p>0.05)$. The TEC values obtained in this study were below the average numbers of erythrocytes in Asian seabass reported by Izwar et al. (2020), i.e., $3.81 \times 106$ cells $/ \mathrm{mm}^{3}$, and Anderson et al. (1996), who used Asian seabass of greater age and weight (6 months old, $210490 \mathrm{~g}$ ), i.e., 3.25-5.20 × $106 \mathrm{cells} / \mathrm{mm}^{3}$. The mean of TLC values from $0 ; 14 ; 30 ; 45$, and 60 days ASE were in the level of $9.20 \pm 3.69 \times 104 ; 7.36 \pm 3.02 \times 104$; $6.80 \pm 2.92 \times 104 ; \quad 7.79 \pm 3.28 \times 104$ and $7.74 \pm 3.43 \times 104$ cells $/ \mathrm{mm}^{3}$, respectively (Figure 4). Overall, despite the TLC tending to decrease from 0 to 60 days ASE, the oneway ANOVA indicated no significant differences in TLC at different ASEs $(p>0.05)$. The TLC values in our Asian seabass were in the range of categorized as high, meaning higher than average TLC levels, i.e., 6.5-56.0 $\times 103$ cells $/ \mathrm{mm}^{3}$ (Anderson et al. 1996).

\section{Discussion}

Similar to a study by Witeska (2013) and Gallaugher (1994), the hematological results that showed low TEC and high TLC indicated that the cultured Asian seabass in the current study were in a condition of less active, anemia, and infected status. Under normal conditions, the TEC levels in less active Teleostei were $0.5-1.5 \times 106$ cells $/ \mathrm{mm}^{3}$, while in more active fish, the values were higher, i.e., 3.0-4.2 × 106 cells $/ \mathrm{mm}^{3}$ (Witeska 2013). Refer to Ordóñez-Grande et al. (2021), and the less active of cultured Asian seabass indicated stress that may be affected by high energy loss due to the high salinity exposure in the floating cage (34.8-36.2 ppt), which is higher than optimum salinity (10-30 ppt) as reported by previous studies by Jamerlan and Coloso (2010), Madrones-Ladja and Catacutan (2012). Regarding the determination of anemia status, Witeska (2013) reported that defining the anemia of fish is difficult due to a lack of clear reference values of red blood parameters. As previously described, was known that the average TEC in our Asian seabass was five times lower than the average TEC of normal Asian seabass. Accordingly, by comparing with the fish hematocrit ratio between normal (30\%) and anemic (27\%), which was reported by Gallaugher (1994) for rainbow trout at rest, suggestive that our Asian seabass were in the health status of anemia.

The highest mean of TLC was found at 0 days ASE $\left(9.20 \pm 3.69 \times 104\right.$ cells $\left./ \mathrm{mm}^{3}\right)$, which hinted that during the first day of cultivation in the floating cage, the fish stock had been in an unhealthy condition related to their immune capacity. The number of leukocytes will increase if the fish is attacked by disease or parasites because leukocytes play a role in phagocytosis and antibody formation (Utami et al. 2013). The TLC is an indicator of the health status of fish because of the role of leukocytes in non-specific or innate immune responses. An increase in the TLC indicates an increase in non-specific defenses due to the activity of macrophages and phagocytic cells (Shahi et al. 2014).

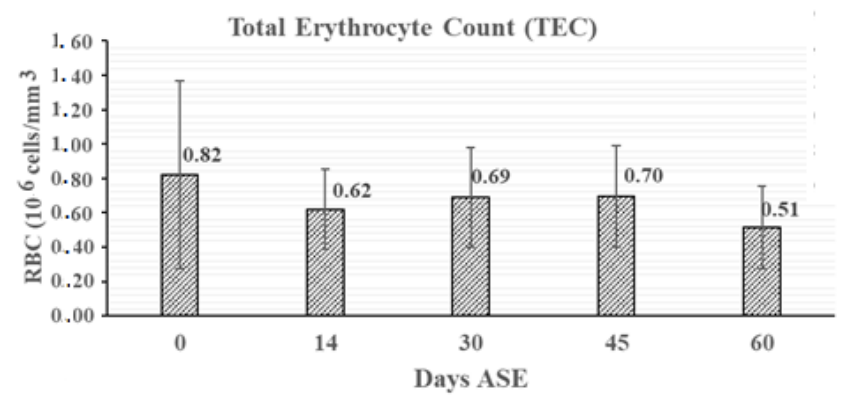

Figure 3. Mean $( \pm \mathrm{SD} / \mathrm{SE}$ ?) of total erythrocyte count (TEC) in Asian seabass cultured in a Sendang Biru floating cage from 0 to 60 days ASE 


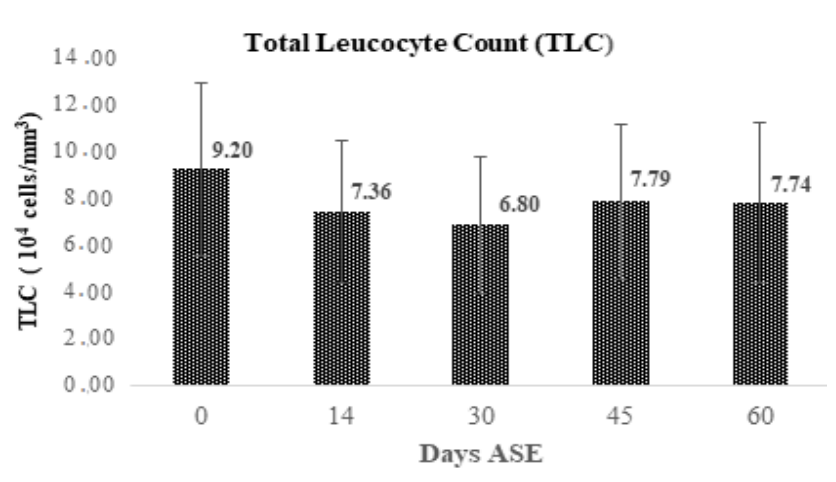

Figure 4. Mean $( \pm \mathrm{SD} / \mathrm{SE}$ ?) of total leukocyte count (TLC) in Asian seabass cultured in a Sendang Biru floating cage from 0 to 60 days ASE

However, the current study revealed that endoparasite intensity of Diphyllobothrium and Pseudoterranova in the cultured Asian seabass were categorized as light, and their prevalence was low. Hence, hypothetically, we suggest that our cultured fish were infected by endoparasites and other pathogenic sources, such as ectoparasites, fungi, or bacteria. By comparison, in a mariculture farm at Hurun Bay, Lampung, Indonesia, cultured Asian seabass were reported as the main target of the ectoparasite Trichodina spp on their gills and operculums, with a high prevalence of $94.3-97.1 \%$ and mean intensity of 156.71-141.91 (Ruckert et al. 2008). This assumption accords with our fish's anemia symptoms, which are possibly associated with ectoparasite infection on the gill, where the parasites act as bloodsuckers and induce hemolytic anemia (Saptiani 2017; Waruiru et al. 2020).

In addition to parasitic sources, fish's hematological condition may be affected by activity and physicochemical water quality (Das and Das 1993). In the early days of cultivation, the stress during handling, transportation, and acclimation might lead to hematological changes and immunosuppression in fish, followed by increased disease susceptibility (Tort 2011; Burgos-Aceves et al. 2019). The acclimation process in an aquaculture system is also one of the factors that can cause stress on fish. According to Akinrotimi et al. (2010), the acclimation process causes a significant reduction in the number of erythrocytes. This can be an indicator of anemia in fish due to the stress during the acclimation process. The handling and transportation of cultured fish can also cause metabolic disorders, enzymatic dysfunction, hematological changes, and other damage (Burgos-Aceves et al. 2019). Therefore, the low TEC levels of the Asian seabass in the current study might be related to acclimation and the low activity levels in the floating cage due to space limitations. Moreover, Figure 3 shows that the trend of TEC declined as ASE increased, which indicates that the fish in the floating cage were possibly stressed since they were exposed to water salinity in the floating cage (34.8-36.2 ppt), which was relatively higher than optimum for Asian seabass growth (10-30 ppt) as recommended by Jamerlan and Coloso (2010) and Madrones-Ladja and Catacutan (2012). Although Asian seabass have a tolerance for high salinity of up to $50 \mathrm{ppt}$ (Schipp et al. 2007), high salinity exposure may affect physiological processes in fish, such as metabolic processes and osmoregulation. Salinity is related to osmotic pressure, which will affect the solubility of ions in water. The higher the salinity, the higher the osmotic pressure (Patterson et al. 2012; Setijaningsih et al. 2019). Moreover, Royan et al. (2014) and Shen et al. (2018) report that environmental changes, including salinity, can lead to abnormal erythrocytes and stress.

The blood profiles revealed that the health statuses of the cultured Asian seabass in our floating cage at Sendang Biru were anemic and infected. The endoparasite prevalence and intensity were categorized as low and light, and hence, the infection was presumably contributed by other pathogenic sources. Further investigation of fish health monitoring, including ectoparasite analysis, is suggested.

\section{ACKNOWLEDGEMENTS}

We are most thankful for the Institut Teknologi Sepuluh Nopember Surabaya (ITS) Indonesia, which provided a research grant and financial support for this work under the project scheme of PPHKI. This research would not have been possible without support from the Laboratory of Zoology and Animal Engineering, Department of Biology, ITS.

\section{REFERENCES}

Agustina LD, Subekti S, Kismiyati. 2018. The prevalence and intensity of gastrointestinal endoparasite worms of cantang grouper (Epinephelus fuscoguttatus lanceolatus) on floating net cages at Lamong Bay Surabaya, Indonesia. IOP Conf Ser Earth Environ Sci 137: 012051. DOI: $10.1088 / 1755-1315 / 137 / 1 / 012051$

Akinrotimi OA, Uedeme-Naa B, Agokei EO. 2010. Effects of acclimation on hematological parameter of Tilapia guineensis (Bleeker, 1862). Sci World J 5 (4): 1-4.

Alagić D. 2009. Aquatic animal health surveillance and disease control system in Bosnia and Herzegovina. In: Bondad-Reantaso MG, Arthur JR, Subasinghe RP (eds). Strengthening Aquaculture Health Management in Bosnia and Herzegovina. FAO, Rome.

Aldon ET. 1997. The culture of seabass. SEAFDEC Asian Aquac 19: 1415.

Al Quraishy S, Abdel-Gaber R, Dkhil MAM. 2019. First record of Pseudoterranova decipiens (Nematoda, Anisakidae) infecting the Red spot emperor Lethrinus lentjan in the Red Sea. Revista Brasileira de Parasitologia Veterinaria 28: 625-631. DOI: 10.1590/s198429612019057

Anderson IG, Schaumuller LF, Kramer HL. 1996. A preliminary study on the hematology of freshwater-reared seabass/barramundi, Lates calcarifer. Asian Fish Sci 9: 101-107.

Anonymous. 2004. Keputusan Menteri Lingkungan Hidup-Indonesia (The Indonesian Minister of Environment) Decree No. 51, 2004. [Indonesian]

Asdary M, Prastowo D, Yuliana, Kusumaningrum I. 2019. Pembesaran ikan kakap putih (Lates calcarifer) dengan sistem resikulasi raceway. Jurnal Perekayasaan Budidaya Air Payau dan Laut 14: 64-69. [Indonesian]

Ashraf M, Zafar A. 2013. Size and organ specificity of different parasites in wild Labeo rohita. Intl J Emerg Trends Pharm Sci 1: 26-32.

Bennett JE, Dolin R, Blaser MJ, Mandell GL, Douglas RG. 2015. Principles and Practice of Infectious Diseases. $8^{\text {th }}$ ed. Elsevier/Saunders, Philadelphia, PA. 
Bennett RH, Ellender BR, Miya T, Pattrick P, Wasserman RJ, Woodford DJ, Weyl OLF. 2016. Ethical considerations for field research on fishes. Koedoe 58 (1): a1353. DOI: 10.4102/koedoe.v58i1.1353

Burgos-Aceves MA, Lionetti L, Faggio C. 2019. Multidisciplinary haematology as prognostic device in environmental and xenobiotic stress-induced response in fish. Sci Total Environ 670: 1170-1183. DOI: 10.1016/j.scitotenv.2019.03.275

Corrêa LL, Bastos LAD, Dos Reis NS. 2015. Hematological and histopathological changes in Hoplias malabaricus from the São Francisco River, Brazil caused by larvae of Contracaecum sp. (Nematoda, Anisakidae). Helminthologia 52: 96-103. DOI: 10.1515/helmin-2015-0018

DPJB. 2017. Laporan Kinerja DPJB (Direktorat Jenderal Perikanan Budidaya Kementerian Kelautan dan Perikanan). Ministry of Marine Affairs and Fisheries, Indonesia. [Indonesian]

Das MK, Das RK. 1993. A review of the fish disease epizootic ulcerative syndrome in India. Environ Ecol 11: 134-145.

Eiras JC, Pavanelli GC, Takemoto RM, Yamaguchi MU, Karkling JC, Nawa Y. 2016. Potential risk of fish-borne nematode infections in humans in Brazil: Current status based on a literature review. Food Waterborne Parasitol 5: 1-6. DOI: 10.1016/j.fawpar.2016.08.002

Gallaugher PE. 1994. The role of haematocrit in oxygen transport and swimming in salmonid fishes. [Thesis]. Simon Fraser University, British Columbia, Canada.

Hastuti SD, Barton MD, Pyecroft SB, Costabile M. 2020. Assay optimization for measuring the alternate complement pathway activity in Asian seabass (Lates calcarifer). Biodiversitas 21 (7): 3034-3040. DOI: 10.13057/biodiv/d210721

Hidayati D, Oclandhi B, Maulidinia N, Sa'adah NN, Nurhayati APD 2019. Short communication: The species and body size composition of pelagic fishes that caught by troll line in the fish landing of Sendang Biru, East Java, Indonesia. Biodiversitas 20 (6): 1764-1769. DOI: $10.13057 /$ biodiv/d200638

Hutson KS. 2014. Infectious diseases of Asian seabass and health management. In: Jerry DR (eds). Biology and Culture of Asian Seabass Lates Calcarifer. CRC Press, Boca Raton, FL, USA.

Izwar A, Nuryati S, Rahman, Purnomowati R. 2020. Isolation, identification, and pathogenicity tests of pathogenic bacterial associated with black body syndrome in white barramundi Lates calcarifer. Jurnal Akuakultur Indonesia 19 (1): 39-49. DOI 10.19027/jai.19.1.39-49. [Indonesian]

Jamerlan GS, Coloso RM. 2010. Intensive Culture of Seabass Lates calcarifer Bloch, in Brackish-water Earthen Ponds. Southeast Asian Fisheries Development Center, Aquaculture Department, Tigbauan, Iloilo, Philippines.

Jithendran KP, Kannappan SA. 2010. Short note on heavy infection of Acanthocephalan worm (Neoechinorhynchus agilis) in grey mullet, Mugil cephalus. J Parasit Dis 34: 99-101. DOI: 10.1007/s12639-0100019-y

Korytáŕ T, Chan JTH, Vancová M, Holzer AS. 2019. Blood feast: Exploring the erythrocyte-feeding behaviour of the myxozoan Sphaerospora molnari. Parasit Immunol 42 (8): 1-7. DOI: 10.1111/pim.12683

Kuchta R, Brabec J, Kubackova P, Scholz T. 2013. Tapeworm Diphyllobothrium dendriticum (Cestoda)-neglected or emerging human parasite? PLoS Negl Trop Dis 7 (12): e2535. DOI: 10.1371/journal.pntd.0002535

Kumar R, Mukherjee SC, Ranjan R, Vani T, Brahmachari RK, Nayak SK. 2015. Effect of dietary supplementation of Bacillus subtilis on haematological and immunological parameters of Catla catla (Hamilton). Aquac Intl 23: 1275-1292. DOI: 10.1007/s10499-0159883-x

Lopez AA, Dwilow R, Bullard J, Mujawar Q. 2020. A case of refractory Diphyllobothriasis in a young pediatric patient. J Ped Infect Dis Soc 0: 4-6. DOI: 10.1093/jpids/piaa001

Madrones-Ladja JA, Catacutan MR. 2012. Net-cage rearing of the Asian seabass Lates calcarifer (Bloch) in brackish-water pond: The technical and economic efficiency of using high protein diets in fingerling production. Philipp Agric Sci 95 (1): 79-86.

NOAA. 2019. National Oceanic and Atmospheric Administration. Department of Commerce, United States. https://www.fisheries.noaa.gov/content/aquaculture-fish-health

Ordóñez-Grande B, Guerreiro PM, Sanahuja I, Fernández-Alacid L, Ibarz A. 2021. Environmental salinity modifies mucus exudation and energy use in European sea bass juveniles. Animals 11 (6): 1580 . DOI: $10.3390 /$ ani1 1061580

Panjvini F, Abarghuei S, Khara H, Paraskoh HM. 2016. Parasitic infection alters haematology and immunity parameters of common carp, Cyprinus carpio, Linnaeus, 1758. J Parasit Dis 40: 1540-1543. DOI: 10.1007/s12639-015-0723-8

Parrino V, Capello T, Costa G, Cannaa C, Sanfilippo M, Fazio F, Fasulo S. 2018. Comparative study of haematology of two teleost fish (Mugil cephalus and Carassius auratus) from different environments and feeding habits. Eur Zool J 85: 193-199. DOI: $10.1080 / 24750263.2018 .1460694$

Patterson J, Bodinier C, Green C. 2012. Effect of low salinity media on growth, condition, and gill ion transporter expression in juvenile Gulf killifish, Fundulus grandis. Comp Biochem Physiol 161: 415-421. DOI: 10.1016/j.cbpa.2011.12.019

Pozio E. 2015. Foodborne Nematodes, Foodborne Parasites in the Food Supply Web: Occurrence and Control. Elsevier, Amsterdam.

Royan F, Rejeki S, Haditomo. 2014. Pengaruh salinitas yang berbeda terhadap profil darah ikan nila (Oreochromis niloticus). J Aquac Manag Technol 3 (2): 109-117. [Indonesian]

Ruckert BS, Palm HW, Klimpel S. 2008. Parasite fauna of Seabass (Lates calcarifer) under mariculture conditions in Lampung. J Appl Ichtyol 24: 321-327. DOI: 10.1111/j.1439-0426.2008.01064.x

Saptiani G, Pebrianto CA, Agustina, Hardi EH, Ardhani F. 2017. Short communication: Diversity and prevalence of ectoparasites associated with cultured fish from coal ponds in East Kalimantan, Indonesia. Biodiversitas 18 (2): 666-670. DOI: 10.13057/biodiv/d180231

Schaperclaus W, Kulow H, Schreckenbach K. 1991. Haematological and serological technique. Fish Dis 1: 71-108.

Schipp G, Bosmans J, Humphrey J. 2007. Northern Territory Barramundi Farming Handbook. Department of Primary Industry, Fisheries and Mines, Darwin Aquaculture Centre, Darwin Northern Territory.

Scholz T, Hector H, Garcia, Kuchta R, Wicht B. 2009. Update on the human broad tapeworm (genus Diphyllobothrium), including clinical relevance. Clin Microbiol Rev 22: 146-160. DOI: $10.1128 / \mathrm{cmr} .00033-08$

Setijaningsih L. 2019. Salinity effect evaluation on the survival rate and hematology of snakeskin gourami juvenile Trichopodus pectoralis. Jurnal Akuakultur Indonesia 18: 193-201. DOI: 10.19027/jai.18.2.193-201. [Indonesian]

Shahi N, Malik SK, Sharma D. 2014. Leukocyte response and phagocytic activity in common carp, Cyprinus carpio experimentally infected with virulent Aeromonas allosaccharophila. J Ecophysiol Occup Health 14: 66-70. DOI: 10.15512/joeoh/2014/v14i1-2/50739

Shamsi S. 2019. Parasite loss or parasite gain? Story of contracaecum nematodes in antipodean waters. Parasit Epidemiol Contr 4: 1-7. DOI: 10.1016/j.parepi.2019.e00087

Shen Y, Wang D, Zhao J, Chen X. 2018. Fish red blood cells express immune genes and responses. Aquac Fish 3: 14-21. DOI: 10.1016/j.aaf.2018.01.001

Siddik MAB, Howieson J, Fotedar R. 2019. Fish and shellfish immunology beneficial effects of tuna hydrolysate in poultry byproduct meal diets on growth, immune response, intestinal health and disease resistance to Vibrio harveyi in juvenile barramundi, Lates calcarifer. Fish Shellfish Immunol 89: 61-70. DOI: 10.1016/j.fsi.2019.03.042

Thépot V, Jerry DR. 2015. The effect of temperature on the embryonic development of barramundi, the Australian strain of Lates calcarifer (Bloch) using current hatchery practices. Aquac Rep 2: 132-138. DOI: $10.1016 /$ j.aqrep.2015.09.002

Tort L. 2011. Stress and immune modulation in fish. Dev Comp Immunol 35: 1366-1375. DOI: 10.1016/j.dci.2011.07.002

Utami DT, Prayitno SB, Hastutui S, Santika A. 2013. Gambaran parameter hematologi pada ikan nila (Oreochromis niloticus) yang Diberi Vaksin DNA Streptococcus iniae dengan dosis berbeda. J Aquac Manag Technol 2: 7-20. [Indonesian]

Waruiru RM, Mbuthia PG, Wanja DW, Mwadime JM. 2020. Prevalence, intensity, and influence of water quality on parasites of farmed fish in Kirinyaga county, Kenya. Livest Res Rural Devel 32: 164.

Williams EH Jr, Bunkley-Williams L. 1996. Parasites of Offshore Big Game Fishes of Puerto Rico and The Western Atlantic. Puerto Rico Department of Natural and Environmental Resources, San Juan, PR, and the University of Puerto Rico, Mayaguez.

Witeska M. 2013. Erythrocytes in teleost fishes: A review. Zool Ecol 23: 275-281. DOI: $10.1080 / 21658005.2013 .846963$ 